\title{
SOME BIOLOGICAL ASPECTS OF GENUS CHRYSICHTHYS IN THE EGYPTIAN INLAND WATERS
}

\author{
Shnoudy A. Bakhoum and Mohamed A. Sayed-Ahmed \\ National Institute of Oceanography and Fisheries, Alexandria, Egypt
}

Key words: Chrysichthys auratus auratus, C. auratus longifilis, $C$. rueppelli, biometric, length-weight relationship, coefficient of condition, natural mortality.

\begin{abstract}
$\mathrm{M}$ eristic and morphometric analyses were used to compare Chrysichthys auratus auratus, Chrysichthys auratus longifitis and Chrysichthys rueppelli from commercial catch of River Nile (A1 Minya) and El-Nozha Hydrodrome (Alexandria). A total of twentynine separate body measurements and counts were taken from each fish. Significant differences were found between Chrysichthys auratus auratus and Chrysichthys auratus longifilis in 4 out of 29 examined characters. These characters were: maximum dorsal rays height, standard length, prepelvic length and dorsal base length. Specific variations revealed that $C$. auratus differed from $C$. rueppelli significantly in eighteen out of twenty-nine examined characters. The univariate and multivariate analyses indicated that $C$. rueppelli was defined from $C$. auratus as the first has larger standard length, relatively short first dorsal fin ray; larger head width; longer upper and lower jaws lengths and caudal peduncle, pectoral fin and prepelvic lengths are longer than that of $C$. auratus. Discriminate function analysis showed that the percent correct site allocation were $96 \%$ for C. auratus auratus, $61 \%$ for C. auratus longifilis and $92 \%$ for. C. rueppelli. All analyses suggested that Chrysichthys auratus and Chrysichthys rueppelli are distinct species. The relative abundance of these species revealed that $C$. auratus auratus dominated the catch by number in both regions. Length-weight relationship and condition factor indicated that $C$. auratus auratus and $C$. auratus longifilis inhabiting El-Nozha Hydrodrome are heavier than those from. River Nile. In addition, the natural mortality coefficient for examined species inhabiting in El-Nozha Hydrodrome was comparatively lower than those from River Nile.
\end{abstract}




\section{INTRODUCTION}

Fishes of genus Chrysichthys are commercially important freshwater African species distributed in Northern Africa: River Nile (Boulenger, 1907), Coast of Ivories, Ghana (Teugels et al., 1988) and Rivers Niger, Volta, Senegal on the West Africa (Paugy et al., 1994 and Ofori-Danson et al, 2002).

According to Boulenger (1907) genus Chrysichthys was divided into two species Chrysichthys auratus and Chrysichthys rueppelli. In addition $C$. auratus has two sub-species namely; $C$. auratus auratus and $C$. auratus longifilis.

Furthermore, Risch (1986 a) in the Checklist of the Freshwater Fishes of Africa (CLOFFA) and Bishai \& Khalil (1997) in an Atlas of Freshwater Fishes of Egypt confirmed the existence of the mentioned two species in the Egyptian inland water.

The present study was conducted to test the meristic and morphometric characters for recognizing Chrysichthys auratus and Chrysichthys rueppelli as distinct species and determine the best biometric characters for distinguishing species and subspecies of this genus were given. In addition, to compare some biological aspects such as length-weight relationship, coefficient of condition, and natural mortality of these species captured from these two different localities (River Nile and El-Nozha Hydrodrome).

\section{MATERIAL AND METHODS}

Samples of Chrysichthys auratus auratus, Chrysichthys auratus longifilis and Chrysichthys rueppelli were collected during the period from February to November 2001 by Seine nets from the commercial catch of the River Nile at Al Minya $\left(31^{\circ} 30^{\prime} \mathrm{E}, 27^{\circ} 45^{\prime} \mathrm{N}\right)$ and ELNozha Hydrodrome, which is an isolated part of Lake Mariut lying in its northeastern side at latitude $31^{\circ} 10^{\prime} \mathrm{E}$ and longitude $30^{\circ} \mathrm{N}$. The latter has a total area of about 504 hectares, its bottom lies at a depth ranging between 3.4 and 3.8 meters below mean sea level and the average water depth is about 2.7 meters (Gharib, 1991). A total of 115,36 and 37 specimens ranging from 104 to $240 \mathrm{~mm}$ total length for Chrysichthys auratus auratus, Chrysichthys auratus longifilis and Chrysichthys rueppelli respectively, were randomly sampled.

The biometric characters examined included twenty-five morphometric measurements taken to the nearest $\mathrm{mm}$ and seven meristic counts. Morphometric measurements were standardized to 
the maximum value of standard length by the method outlined by Beacham and Murray (1983). This allometric regression to a standard size is a preferred method of removing size variation in characters among individuals (Reist, 1985). The meristic and size-adjusted data sets were analyzed univariately by using Kolmorov-Simirnov test (Haddon and Willis, 1995) and multivariately by the method of discriminant function analysis (Henault and Fortin, 1989).

Length-weight relationship was determined from the formula of Le Cren (1951), the gutted weight was used in order to exclude the effect of stomach contents and weight of gonads (Lagler, 1956; Ricker, 1975). The coefficient of condition (K) was calculated from the equation:

$\mathrm{K}=100 \mathrm{~W} / \mathrm{L}^{3}$ (i.e. Fulton condition factor)

Where $\mathrm{W}=$ gutted weight in grams, $\mathrm{L}=$ total length in $\mathrm{cm}$.

This factor is often assed as an approximation even when the allometric factor is theoretically more appropriate (Bagenal and Braum, 1971; Ricker, 1975). Data of length-weight relationship and condition factor were statistically analyzed using covariance and ANOVA respectively. The natural mortality coefficient " $\mathrm{M}$ " was calculated by the method described by Ursin (1967).

\section{RESULTS}

$\therefore$ The morphological features for Chrysichthys auratus auratus, Chrysichthys auratus longifilis and Chrysichthys rueppelli are shown in Figure 1. The meristic counts and morphometric characters examined in this study are summarized in Table 1.

\section{Inter-specific variations}

Comparing the meristic counts and morphometric measurements of C. auratus auratus with C. auratus longiflis Kolmogorov Smimov test revealed that this subspecies differed significantly in 4 out of 29 examined characters. These characters were: maximum dorsal rays height; pectoral fin length; prepelvic length and caudal peduncle length (Table 2).

Squared Mahalanobis distance (6.508) between $C$. auratus auratus and C. auratus longifilis was significantly differed ( $F=5.271$, $\mathrm{p}<0.001$ ). Furthermore, stepwise discriminate function analysis showed significant difference between these sub species (Wilks'Lambda: $0.607, F=5.596, p<0.0001$ ). This analysis indicated that the best characters for distinguishing $C$. auratus auratus from $C$. 
auratus longifilis are the following: maximum dorsal rays height (Fremove $=33.646, p<0.0001$ ), standard length ( $F$-remove $=7.601$, $p<0.01)$, prepelvic length $(F$-remove $=6.695, p<0.01)$ and dorsal base length ( $F$-remove $=6.540, p<0.01$ ).

\section{Specific variations}

Concerning variations in biometric characters between $C$. auratus and $C$. rueppelli, the results of Kolmogorov-Smirnov test revealed that eighteen out of twenty-nine characters differed significantly (Table 3).

Squared Mahalanobis distance between these species (28.259) was significant ( $F=16.824, \mathrm{p}<0.001$ ). Moreover stepwise discriminate function analysis showed significant differences between $C$. auratus and $C$. rueppelli (Wilks'Lambda: 0. 245, $F=17.604, p<0.0001$ ). The percent correct site allocation was high for these species, $99.35 \%$ for C. auratus and $88.89 \%$ for C. rueppelli. The significant characters that can use for distinguish $C$. auratus from $C$. rueppelli are, standard length ( $F$-remove $=40.021, p<0.0001$ ), maximum dorsal rays height (F-remove $=15.068, p<0.001)$, and head width $(\mathrm{F}$-remove $=9.623$, $\mathrm{p}<0.01$ ), upper jaw length (F-remove $=8.526, \mathrm{p}<0.01$ ), lower jaw length ( $F$-remove $=7.348, \mathrm{p}<0.01$ ), caudal peduncle length ( $F$-remove $=6.225, \mathrm{p}<0.01$ ), pectoral fin length $(\mathrm{F}$-remove $=4.370, \mathrm{p}<0.05)$ and prepelvic length (F-remove $=3.946, \mathrm{p}<0.05)$.

Canonical discriminant-factor scores obtained using biometric data revealed that the percent correct site allocation were $96 \%$ for $C$. auratus auratus, $61 \%$ for C. auratus longifilis and $92 \%$ for $C$. rueppelli (Fig.2).

\section{Species composition}

The relative aburidance of these species (Table 4) in El-Nozha Hydrodrome indicated that $C$. auratus auratus dominated the catch by number $(47.78 \%)$, followed by $C$. auratus longifilis $(26.67 \%)$ and $C$. rueppelli $(25.56 \%)$. Conceming numerical abundance in the River Nile at Al Minya C. auratus auratus was more abundant than in ElNozha Hydrodrome ( $74.23 \%$ ) and ranks first followed by C. rueppelli $(13.40 \%)$ and C. auratus longifilis (12.37\%).

\section{Length-weight relationship}

The computed length-weight relationships of the mentioned species from these different regions showed significant differences in the regressions of $C$. auratus auratus $(\mathrm{F}=14.024, \mathrm{p}<0.01)$ and $C$. auratus longifilis, $(\mathrm{F}=68.957, \mathrm{p}<0.0001)$, while $C$. rueppelli revealed no significant difference $(F=2.613, p>0.05)$. 
The relationships of total length (L) versus gutted weight (W) for them in different habitats were expressed:

A- For El-Nozha Hydrodrome

C. auratus auratus: $\log \mathrm{W}=-1.774+2.865 \log \mathrm{L}(\mathrm{r}=0.9973)$

C. auratus longifilis: $\log W=-1.787+2.866 \log L(r=0.9871)$

C. rueppelli: $\log \mathrm{W}=-1.794+2.874 \log \mathrm{L}(\mathrm{r}=0.9871)$

B- For River Nile at Al Minya

C. auratus auratus: $\log W=-1.596+2.664 \log \mathrm{L}(\mathrm{r}=0.9902)$

C. auratus longifilis: $\log W=-1.827+2.824 \log \mathrm{L}(\mathrm{r}=0.9945)$

C. rueppelli: $\log W=-1.491+2.594 \log \mathrm{L}(\mathrm{r}=0.9604)$

The mean of observed and calculated values of fish from these two localities is given in Table 5.

\section{Condition factor}

$\therefore$ The values of condition factor at different length groups of the examined species from both habitats are shown in Table 6 . The mean values of condition fastors for fishes from El-Nozha Hydrodrome were higher than those from the River Nile, whereas these values were: 1.136 and 1.066 for $C$. auratus auratus; 1.137 and 1.016 for $C$. auratus longifilis and 1.146 and 1.039 for $C$. rueppelli. The difference in condition factor for examined species from these two regions were statistically tested using analysis of variance. This test indicates that there are significant differences in the mean values of condition factor for $C$. auralus auratus $(\mathrm{F}=6.954, \mathrm{p}<0.01)$ and $C$. auratus longifilis, $(\mathrm{F}=11.911, \mathrm{p}<0.01)$, while $C$. rueppelli revealed no significant difference $(F=2.867, p>0.05)$, i.e. fishes of species $C$. auratus inhabiting El-Nozha Hydrodrome are heavier than those from the River Nile.

\section{Natural mortality}

Comparing natural mortality coefficient $(M)$ of these species from the two localities indicated that, the natural mortality coefficient for $C$. auratus auratus $(\mathrm{M}=0.234) ; C$. auratus longifilis $(\mathrm{M}=0.233)$ and C. rueppelli $(M=0.245)$ of fish inhabting El-Nozha Hydrodrome were comparatively lower than those for $C$. auratus auratus $(\mathrm{M}=$ $0.318) ; C$. auratus longifilis $(\mathrm{M}=0.368)$ and $C$. rueppelli $(\mathrm{M}=0.286)$ of the River Nile. Analysis of variance revealed that there are significant differences in the natural mortality for $C$. auratus auratus $(\mathrm{F}=88.236, \mathrm{p}<0.001)$ and $C$. auratus longifilis, $(\mathrm{F}=150.700$, $\mathrm{p}<0.001)$ and $C$. rueppelli $(\mathrm{F}=5.561, \mathrm{p}<0.05)$. These results suggest that environmental conditions in the River Nile are more suitable for these species than in El-Nozha Hydrodrome. 


\section{DISCUSSION}

The morphological data in this study indicate that Chrysichthys auratus auratus differs from Chrysichthys auratus longifilis only in four out of twenty-nine examined characters. The univariate and multivariate analyses revealed that the first ray of dorsal fin is the most striking difference between these two sub-species concerned as it is relatively longer in the second than in the first one. This character is the main character for distinguishing these sub-species (Burgess, 1989). Also $C$. auratus longifilis has longer pectoral fin length and larger prepelvic and caudal peduncle lengths. Risch (1986 b) attributed the differences in the length of first soft dorsal fin ray to the maturity stage. He found that males, which are often without a dorsal filament, were found with females, often with a filament, in the same nest and all specimens without filaments examined from the Nile deme were sexually mature.

The high significant differences in morphometric measurements (18 out of 29 characters) were recorded between Chrysichthys auratus and Chrysichthys rueppelli leads us to conclude that they are distinct species. The discriminate function analysis supports the results of Kolmogorov-Smirnov test in suggesting that these two species can often be distinguished by their overall body shapes. Whereas the percent correct allocation was $96 \%$ for $C$. auratus and $92 \%$ for $C$. rueppelli. Furthermore, from the significant characters, which were determined by this analysis we can differentiate between C. rueppelli from $C$. auratus by the following: $C$. rueppelli has relatively short first dorsal fin ray; larger head width; longer upper and lower jaws lengths, caudal peduncle, pectoral fin and prepelvic lengths are longer than that of $C$. auratus.

In spite of Rischs (1986 a) findings on genus Chrysichthys in Egyptian inland water, he identified C. rueppelli and C. auratus as different species, but later in his study on the systematic revision of this genus he considered the nominal species $C$. rueppelli as a junior synonym of $C$. auratus (Risch, 1986 b). The present study is in agreement with Bishai \& Khalil (1997) and Eschmeyer \& Editor (1998) as C. rueppelli and C. auratus are separate species. In addition, Zaki et al. (1997) deffrentated C. rueppelli from C. auratus by using phast gel isoelectric focusing method. They found that $C$. rueppelli and $C$. auratus are two completely separate species, whereas each species has a characteristic, species- specific 
electrophoretic pattern of the protein fractions in the eye lens, flesh and skin.

According to Lagler et al. (1977), the length-weight relationship leads itself to a comparison of individuals within and between different populations. In the present investigation it was found that there are significant differences between regressions of both subspecies of $C$. auratus from El-Nozha Hydrodrome and the River Nile. Moreover, the results revealed that the mean values of condition factor for $C$. auratus auratus and $C$. auratus longifilis were significantly higher for fish inhabiting El-Nozha Hydrodrome than for fish from River Nile, i.e. fishes of species C. auratus inhabiting in El-Nozha Hydrodrome are heavier than those from the River Nile.

According to Ricker (1971), condition factor gives an indication of the degree of the well being of fish and it is used to indicate the suitability of an environment for a certain fish species by comparison with another envirenment In addition, the natural morlality coefficient for the examined species inhabiting in El-Nozha Hydrodrome was comparatively lower than those the from the River Nile indicating that environmental conditions in El-Nozha Hydrodrome are more suitable for the mentioned species. Increasing the values of Length-weight relationship and condition factor for $C$. auratus inhabiting in El-Nozha Hydrodrome may be attributed to relatively higher fertility in phytoplankton gtown up as the increasing the level of different nutrients. This is in agreement with the finding of Elgayar and Elewa (1990) who mentiond that using agricultural fertilizers (ammonium nitrate and tri-super phosphate) in El-Nozha Hydrodrome caused the fertility of the water media to be enhanced and accelerated the growth of fish remarkably.

\section{REFERENCES}

Beacham, T. D. and Murray, C. B. (1983). Sexual dimorphism in the adipose Indo Pacific salmon (Oncorhynchus). Can. J. Fish. Aquat. Sci., 40:2019- 2024.

Bagenal, T. B. and Braum, E., (1971) Eggs and early life history. In: Methods for Assessment of Fish production in fresh water: I.B.P. Blackwell Scient. Publ. Oxford \& Edinburgh. 165$201 \mathrm{pp}$.

Bishai, H. M. and Khalii, M. T. (1997). Freshwater Fishes of Egypt. National Biodiversity Unit, Cabinet of ministers Egyptian Environment Affairs Agency (E E A A ), A.R.E. (9): 229pp. 
Boulenger, G. A., (1907). The Zoology of Egypt: The Fishes of the Nile. Hugh Reet, Publication, Ltd., Londor.

Burgess, W. E. (1989). An Atlas of Freshwater and Marine catfishes: A Preliminary Survey of the Siluriformes. T. F. H. Publications, Neptune City, New Jersey.

Elgayar, F: and Elewa, F. (1990). Tilapia production in polyculture of El-Nozha Hydrodrome Lake of Alexandria.International Symposium on Biology and Culture of Tilapias. 27-31 October. Alexandria, Egypt, 253-264.

Eschmeyer, W. and Editor, N. (1998). Catalog of fishes. Special Publication, California Academy of Sciences, San Francisco, 3: $2905 \mathrm{pp}$.

Gharib, S. M. (1991). Study of the biological productivity of the Nozha Hydrodrome as a model of artificially fertilized fish farm. Ph.D. Thesis FaC. Sci. Mansoura Univ., 453pp.

Haddon, M. and Willis, T. J. (1995). Morphometric and meristic comparison of orange roughy (Hoplostethus atlanticus : Trachichthyidae) from the Puysegur Bank and Lord Howe Rise, New Zealand, and its implications for stock structure. Marine Biology, 123: 19-27.

Henault, M. and. Fortin, R. (1989). Comparison of meristic and morphometric characters among spring-and fall-spawning ecotype of Cisco (Coregonus artedii) in southern Quebec, Canada. Can. J. Fish. Aquat. Sci., 46: 166-173.

Lagler, K. F. (1956). Fresh Water Fishery Biology (Brown W.M.C. comp., eds.) Dubuque, Iowa, $421 \mathrm{pp}$.

Lagler, K. F. ; Baradach, J. E and Miller, R. R., (1977). Ichthyology. In: Growth of fishes. John Wiley \&Sons, New York, London, Sydney, 163-168.

Le Cren, E. D. (1951).The length-weight relationship and seasonal cycle in gonad in gonad weight and condition in the perch (Perca fluviatilis). J. Anim. Ecol. 20 (2): 201-219. 
Ofori- Danson, P. K. ; de Graaf, G. J. and Vanderpuye, C. J. (2002). Population Parameters estimates for Chrysichthys auratus and $C$. nigrodigitatus (Pisces: Claroteidae) in Lake Volta, Ghana.Fisheries Research 54 (2): 267- 277.

Paugy, D. ; Traore, K. and Diouf, P. S. (19940. Faune ichtyologique des eaux douces d' Afrique de I' Ouest. In: Teugels, G.G.; Guegan, J. F. and Albaret, J.J. (eds.) Biological Diversity of African fresh-and brackish water fishes. 35-66 pp.Geographical overviews presented at the PARADI Symposium, Senegal, 15-20 November 1993. Ann. Mus. R. Af. Centr., Sci. Zool.27pp.

Ricker, W. E. (1971). Iriethods for Assessment of Fish Production in Fresh Water. IBP Blackwell Scientific Publication.

Ricker, W. E. (1975). Computation and interpretation of biology statistics for fish population. Bull. Fish. Res. Bd. Can. 119, 200 pp.

Risch, L. M. (1986) a. Bagridae. In Daget, J.; Gosse, J. P. and Thys van Den, D. F. E., Audenaerde (eds.) Check- list of the Freshwater Fishes of Africa (CLOFFA). ISNB, Brussels; MRAC, Tervuren and ORSTOM, Paris, 2: 2-35.

Risch, L.. M. (1986b). Het genus Chrysichthys Bleeker, 1858 en aanverwante genera (Pisces, Siluriformes, Bagridae) een systematisch, morfologische, anatomische en zoogeografische studie. $\mathrm{Ph}$ D. Thesis, Katholieke Universiteit Leuven, Belgium, 506 pp.

Reist, J. D. (1985). An empirical evaluation of several univariate methods that adjust for size variation in morphometric data. Can J. Zool., 63:1429-1439.

Teugels, G. G. ; Leveque, C. ; Paugy, D. and Traore, K. (1988). Tat des connaissances sur la faune ichtyologique des basins cotiers de Cote d' Ivoire et de I'ouest du Ghana. Rev. Hydrobiol. trop, 21(3): 221-237. 
Ursin, E. (1967). A mathematical model of some aspects of fish growth respiration and mortality. J. Fish. Res. Bd. Canada. 24 (2): $2355-2453$.

Zaki, M. I. ; Abd-Elgawad, A. M and Fahmy, A. F. (1997). Identification of two species of subfamily (Bagrinea) namely: Chrysichthys rueppelli and Chrysichthys auratus using isoelectric focusing technique. Bull. Nat. Inst. Oceanogr. \& Fish., A.R.E., 23: 427-438. 


\section{SOME BIOLOGICAL ASPECTS OF GENUS CHRYSICHTHYS 269 IN THE EGYPTIAN INLAND WATERS}

Table (1): Comparison of meristic and morphometric measurements of Chrysichthys auratus auratus, Chrysichthys auratus tongifflis and Chrysichthys rueppelli.

\begin{tabular}{|c|c|c|c|}
\hline & $\begin{array}{l}\text { C.auratus auratus } \\
\text { Mean+SD(Range) }\end{array}$ & $\begin{array}{l}\text { C. auratus longifilis } \\
\text { Mean+Sp(Range) }\end{array}$ & $\begin{array}{l}\text { C. rueppelli } \\
\text { MeantSD(Range) }\end{array}$ \\
\hline \multicolumn{4}{|l|}{ Meristic count } \\
\hline Dorsal fin (spines, rays) & 1,6 & 1,6 & 1.6 \\
\hline Pectoral fin (spines, rays) & 1,7 & 1.7 & 1.7 \\
\hline Ana: fin rays & $10.30 \pm 0.610(9-12)$ & $10.28 \pm 0.705(9-11)$ & $10.36 \pm 0.683(9-11)$ \\
\hline Vertebrae (total) & $34.48 \pm 1.161(31-37)$ & $34.50 \pm 1.000(33-36)$ & $34.07 \pm 1.335(32-36)$ \\
\hline \multicolumn{4}{|l|}{ Morphometric characters } \\
\hline Total kength & $163.57 \pm 33.219(106-280)$ & $168.81 \pm 39.342(104-240)$ & $197.64 \pm 31.334(103-222)$ \\
\hline Standard length & $136.57 \pm 28.131(87-233)$ & $142.86 \pm 34.410(90-216)$ & $150.72 \pm 26.441(87-187)$ \\
\hline Predorsal length & $49.32 \pm 10.653(30-84)$ & $51.14 \pm 11.233$ (34-69) & $54.42 \pm 9.566(32-71)$ \\
\hline Preanal tength & $97.22 \pm 21.030(62-166)$ & $104.33 \pm 27.130(62-170)$ & $108.83 \pm 20.795(60-139)$ \\
\hline Prepectoral length & $31.39 \pm 7.116(18-54)$ & $34.22 \pm 9.166(20-59)$ & $36.50 \pm 7.599(18-50)$ \\
\hline Prepelvic length & $71.52 \pm 14.744(-47-121)$ & $75.00 \pm 18.652(37-103)$ & $79.72 \pm 13.350,46-104)$ \\
\hline Preadipose length & $94.56 \pm 19.915(48-167)$ & $97.94 \pm 22.603(59-133)$ & $104.28 \div 19.477(58-137)$ \\
\hline Dorsal base length & $17.96 \pm 3.335(12-27)$ & $18.58 \pm 3.307(13-26)$ & $19.11 \pm 3.396(11-24)$ \\
\hline Max dorsal rays height & $33.64 \pm 7.731(21-53)$ & $40.72 \pm 11.034(23-62)$ & $35.28 \pm 6.819(19-49)$ \\
\hline Anal base length & $15.92 \pm 3.574(9.29)$ & $-16.42 \pm 3.835(11-23)$ & $47.58 \pm 3.442(10-24)$ \\
\hline Pelvic base length & $19.33 \pm 3.929(12-31)$ & $20.36 \pm 4.530(12-30)$ & $22.50 \pm 8.409(14-67)$ \\
\hline Pectoral in length & $23.37 \pm 5.402(13-41)$ & $25.19 \pm 6.484(14-40)$ & $24.69 \pm 5.170(16-39)$ \\
\hline Max body depth & $29.25 \pm 5.867(19-46)$ & $31.39 \pm 7.173(19.43)$ & $30.83 \pm 8.413(16-48)$ \\
\hline Head length & $43.12 \pm 9.610(27-77)$ & $44.39 \pm 10.979(18-62)$ & $48.53 \pm 8.467(28-61)$ \\
\hline Snout length & $16.65 \pm 3.860(9-29)$ & $17.53 \pm 4.632(10-26)$ & $18.69 \pm 4.027(11-25)$ \\
\hline Pregill oover & $37.38 \pm 8.475(24-69)$ & $39.31 \pm 9.402(25-54)$ & $43.14 \pm 7.076(26-54)$ \\
\hline interorbital width & $14.77 \pm 3.652(7-25)$ & $16.25 \pm 4.569(8-24)$ & $16.67 \pm 4.050(9-24)$ \\
\hline Eye diameter & $10.08 \pm 1.574(6-14)$ & $10.11 \pm 1.582(7-13)$ & $10.64 \pm 1.839(6-14)$ \\
\hline Head depth (through eyes) & $18.30 \pm 3.905(11-33)$ & $18.69 \pm 4.634(12-27)$ & $20.53 \pm 3.791(12-28)$ \\
\hline Max.head depth & $22.50 \pm 4.983(13-38)$ & $23.19 \pm 5.696(12-34)$ & $24.42 \pm 5.978(14-38)$ \\
\hline Upper jaw length & $14.90 \pm 4.091(8-30)$ & $15.69 \pm 4.335(9-24)$ & $19.17 \pm 3.939(11-30)$ \\
\hline Lower jaw length: & $12.61 \pm 3.415(7-24)$ & $13,42 \pm 3.813(7-21)$ & $16.53 \pm 3.730(9-26)$ \\
\hline Head width & $28.24 \pm 6.112(19-53)$ & $28.58 \pm 6.115(19-42)$ & $34.20 \pm 6.077(17-44)$ \\
\hline Caudal peduncle depth & $12.60 \pm 2.540(8-22)$ & $13.22 \pm 2.987(8-19)$ & $13.78 \pm 2.531(\mathrm{~B}-17)$ \\
\hline Caudal peduncle length & $24.06 \pm 4.871(15-43)$ & $25.31 \pm 5.835(16-37)$ & $26.61 \pm 4.680(16-35)$ \\
\hline
\end{tabular}


Table (2):Kolmogorov-Smimov tests for the differences in meristic and morphometric measurement of Chrysichthys auratus auratus and Chrysichthys auratus longiflis Significance levels: ${ }^{*} p<0.05 ;{ }^{*} p<0.01$ and ${ }^{* * *} p<0.001$.

\begin{tabular}{|lll|}
\hline \multicolumn{1}{|c|}{ Eiometric characters } & & \\
& & \\
& & \\
Meristic counts & & \\
Anal fin rays & -0.0889 & $p=n . s$. \\
Vertebrae (total) & -0.1298 & $p=n . s$. \\
Morphometric characters & & \\
Standard length & -0.2237 & $p=n . s$. \\
Preanal length & -0.2241 & $p=n . s$. \\
Prepectoral length & -0.2160 & $p=n . s$. \\
Prepelvic length & -0.2926 & $p<0.05$ \\
Preadipose length & 0.0721 & $p=n . s$. \\
Dorsal base length & -0.2019 & $p=n . s$. \\
Maximum dorsal rays height & -0.4696 & $p<0.001$ \\
Anal base length & -0.1348 & $p=n . s$. \\
Peivic base length & -0.1869 & $p=n . s$. \\
Pectoral fin length & -0.3117 & $p<0.01$ \\
Maximum body depth & -0.2264 & $p=n . s$. \\
Head length & 0.0517 & $p=n . s$. \\
Snout length & -0.2509 & $p=n . s$. \\
Pregill cover & -0.2300 & $p=n . s$. \\
Interorbital width & -0.2155 & $p=n . s$. \\
Eye dianreter & 0.1429 & $p=n . s$. \\
Head depth (through eyes) & 0.1248 & $p=n . s$. \\
Maximum head depth & -0.1534 & $p=n . s$. \\
Upper jaw length & -0.1661 & $p=n . s$. \\
Lower jaw length & -0.2264 & $p=n . s$. \\
Head width & 0.2128 & $p=n . s$. \\
Caudal peduncle depth & -0.1960 & $p=n . s$. \\
Caudal peduncle length & -0.2868 & $p<0.05$ \\
& & \\
\hline
\end{tabular}


Table (3):Kolmogorov-Smimov tests for the differences in meristic and morphometric measurement of Chrysichthys auratus and Chrysichthys rueppelli.

Significance levels: ${ }^{*} p<0.05 ;{ }^{* *} p<0.01$ and ${ }^{* * *} p<0.001$.

\begin{tabular}{|c|c|c|}
\hline Biometric characters & Maximum Difference & ptevel \\
\hline \multicolumn{3}{|l|}{ Meristic counts } \\
\hline Anal fin rays & -0.0915 & $p=$ n.s. \\
\hline Vertebrae (total) & -0.2131 & $p=$ n.s. \\
\hline \multicolumn{3}{|l|}{ Morphometric characters } \\
\hline Standard lergth & 0.2582 & $p<0.05$ \\
\hline Preanal length & -0.7056 & $p<0.001$ \\
\hline Prepectoral length & -0.2958 & $p<0.05$ \\
\hline Prepelvic length & -0.5980 & $p<0.001$ \\
\hline Preadipose length & -0.7173 & $p<0.001$ \\
\hline Dorsal base length & -0.2990 & $p<0.05$ \\
\hline Maximum dorsal rays height & -0.4918 & $p<0.001$ \\
\hline Anal base length & -0.1337 & $p<0.01$ \\
\hline Pelvic base length & -0.2958 & $p<0.05$ \\
\hline Pectoral fin length & -0.4363 & $p<0.001$ \\
\hline Meximum body depth & -0.3628 & $p<0.001$ \\
\hline Head length & 0.5245 & $p<0.001$ \\
\hline Snout length & -0.2435 & $p=$ n.s. \\
\hline Pregill cover length & -0.3007 & $p<0.05$ \\
\hline Interorbital width & 0.2353 & $p=n . s$ \\
\hline Eye diameter & 0.3105 & $p<0.01$ \\
\hline Head depth (through eyes) & 0.2614 & $p<0.05$ \\
\hline Maximum head depth & -0.3709 & $p<0.001$ \\
\hline Upper jaw length & 0.1650 & $p=n . s$. \\
\hline Lower jaw length & 0.1977 & $p=n . s$. \\
\hline Head width & 0.1128 & $\mathbf{p}=\mathbf{n} . \mathbf{s}$. \\
\hline Caudal peduncle depth & -0.2663 & $p<0.05$ \\
\hline Cauctal peduncle length & -0.3415 & $p<0.01$ \\
\hline
\end{tabular}




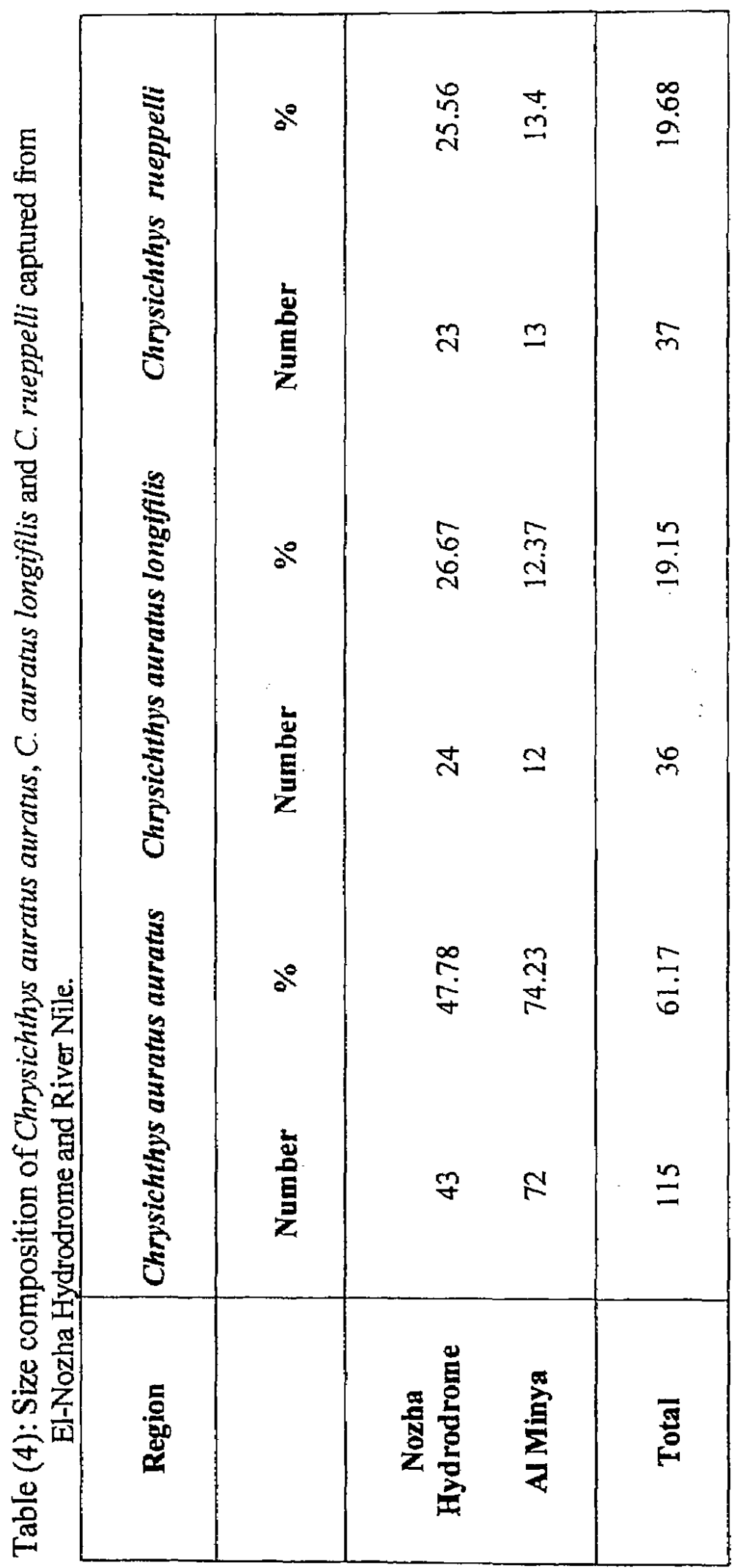




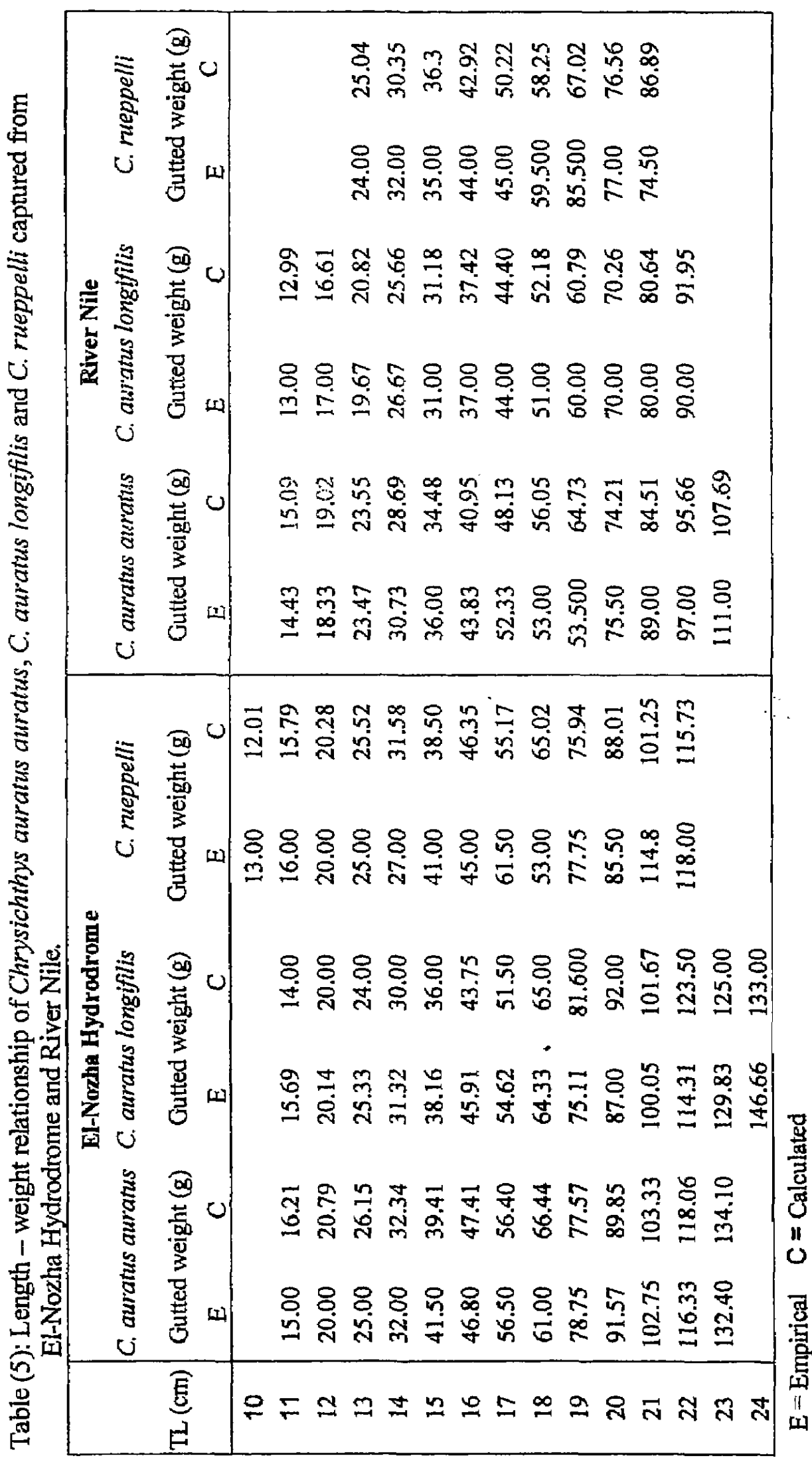




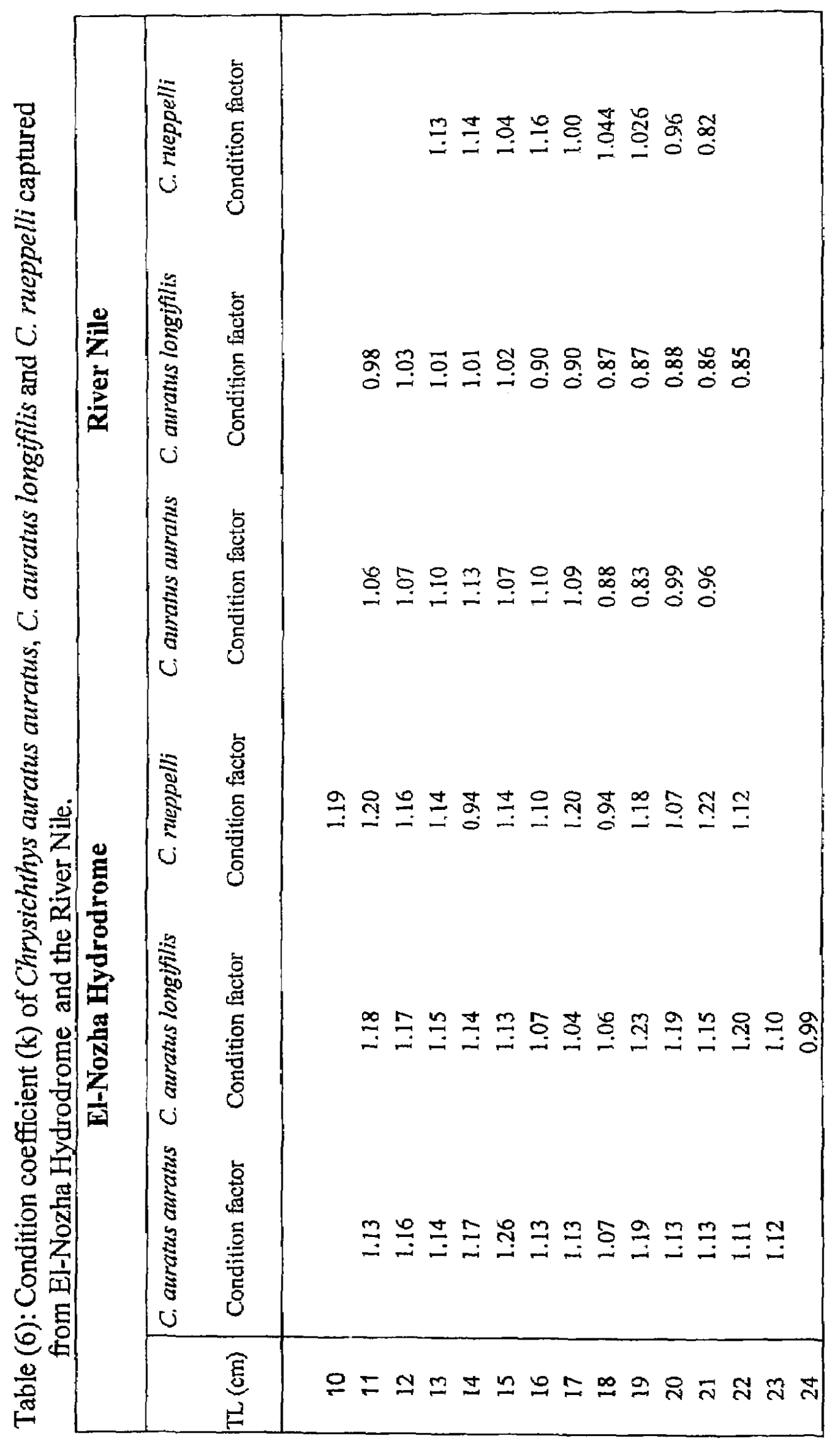




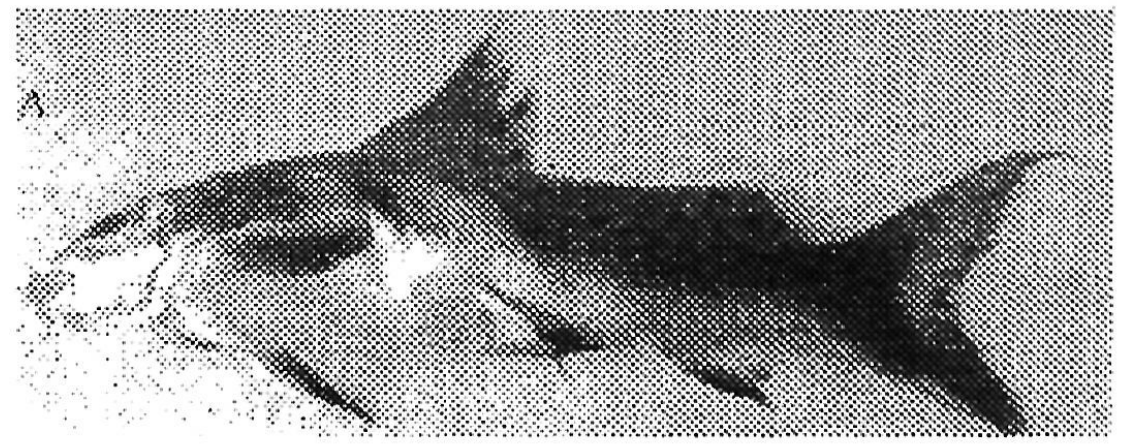

Chrysichtitys actrous

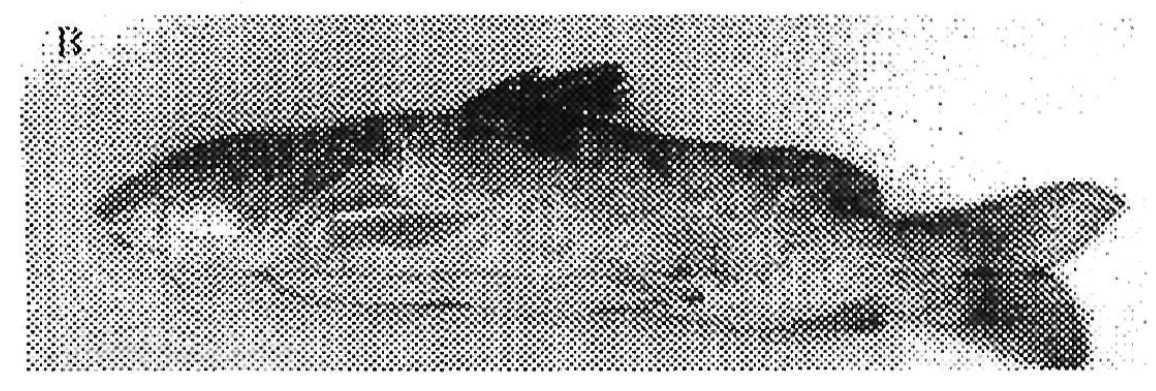

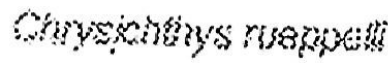

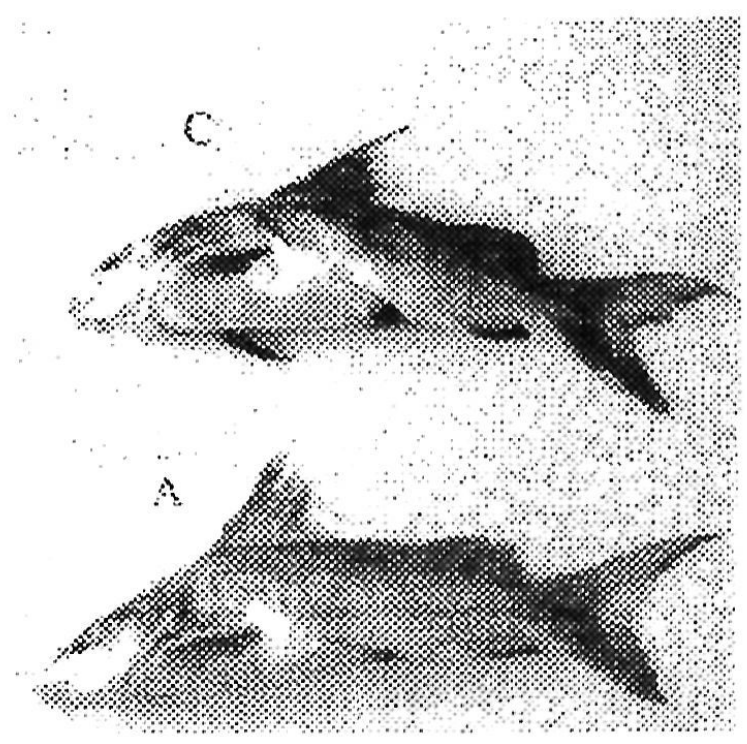

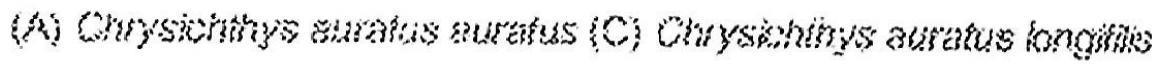

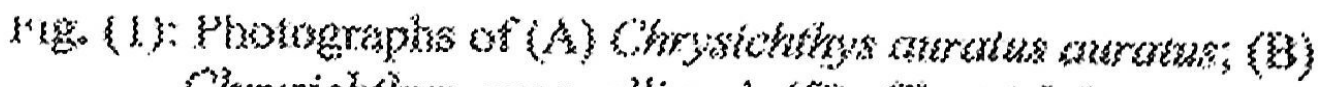

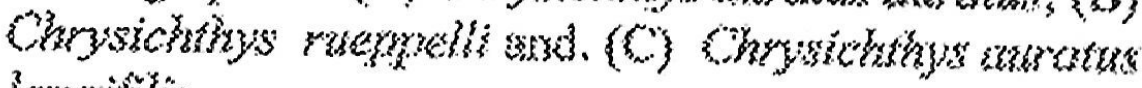
inngiverys 


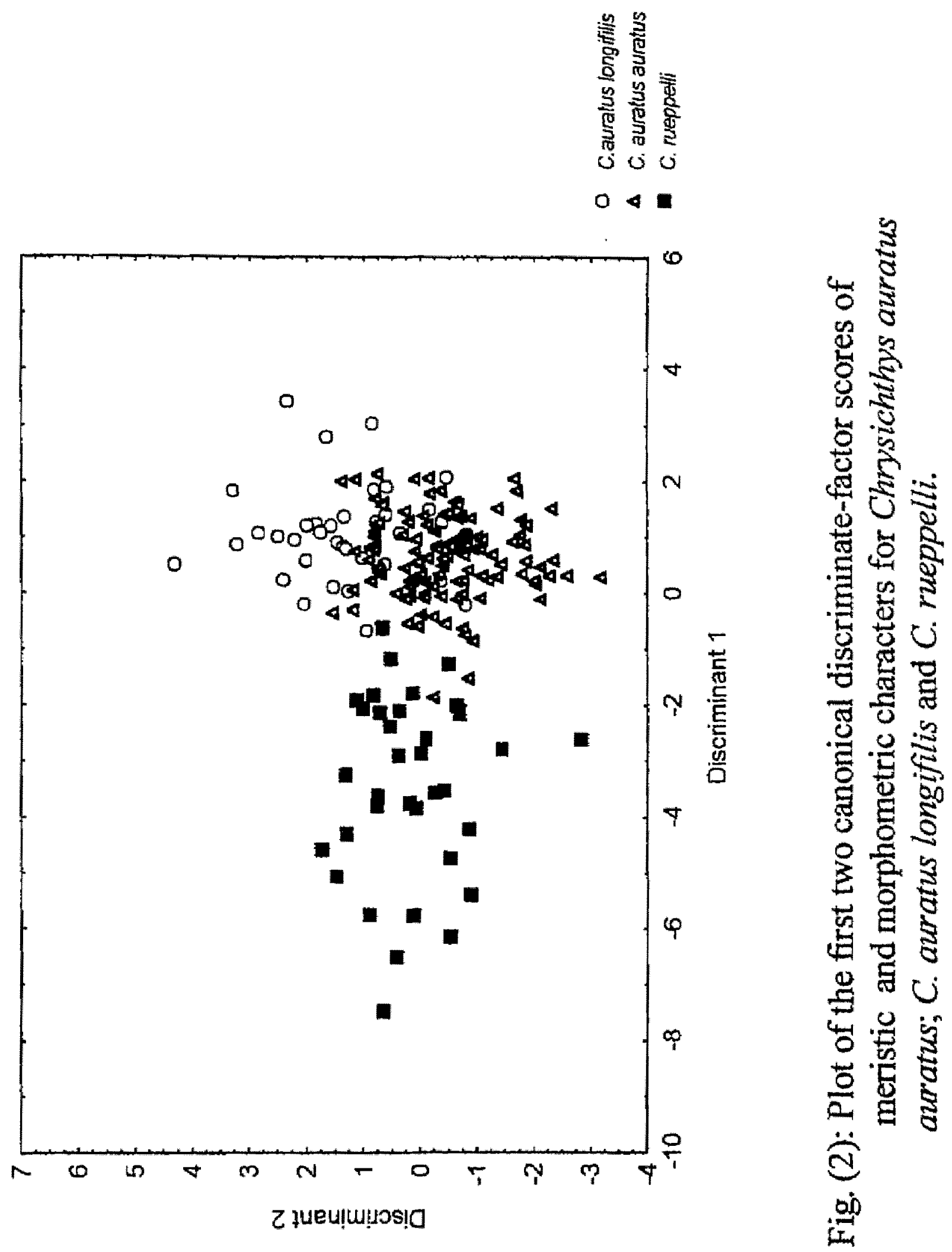

